\title{
Pengaruh Pengungkapan Corporate Social Responsibility terhadap Earnings Response Coefficient pada Perusahaan yang Terdaftar di Bursa Efek Indonesia 2014
}

\author{
Natalia Poerwanto \\ Jurusan Akuntansi/Fakultas Bisnis dan Ekonomika \\ nataliapoerwanto@yahoo.com
}

\begin{abstract}
Abstrak -Penelitian ini bertujuan untuk menguji pengaruh pengungkapan aktivitas Corporate Social Responsibility dalam laporan tahunan perusahaan terhadap Earnings Response Coefficient. Sampel dalam penelitian ini diambil dari perusahaan yang terdaftar pada Bursa Efek Indonesia tahun 2014. Pengolahan data dilakukan menggunakan analisis regresi linier berganda dengan model interaksi. Hasil penelitian menunjukkan bahwa pengungkapan CSR tidak memiliki pengaruh signifikan terhadap ERC. Hal itu disebabkan karena minimnya informasi yang diungkapkan perusahaan terkait aktivitas CSR dalam laporan tahunan dan investor tidak sepenuhnya percaya terhadap informasi tersebut.

Kata Kunci: Earnings Response Coefficient (ERC), Pengungkapan Corporate Social Responsibility (CSR)
\end{abstract}

Abstract -This study aimed to examine the effect of Corporate Social Responsibility activity disclosed in the companies' annual reports on the Earnings Response Coefficient. The sample in this study was drawn from companies listed on Indonesia Stock Exchange in 2014. Tests carried out using multiple linear regression analysis with interaction models. The results show that the disclosure of CSR does not significantly affect the ERC. It is caused due to lack of CSR information disclosed by companies and investors do not fully confidence toward that information.

Keywords: Earnings Response Coefficient (ERC), Corporate Social Responsibility (CSR) disclosure

\section{PENDAHULUAN}

Informasi laba perusahaan merupakan informasi penting bagi pertimbangan investor dalam pengambilan keputusan investasi. Hal itu dikarenakan informasi laba dianggap sebagai informasi yang paling relevan dalam menggambarkan kinerja perusahaan. Informasi laba akan diperoleh investor melalui laporan keuangan perusahaan. Angka laba diperkirakan dapat memfasilitasi analis dan investor untuk meramalkan aliran kas di masa depan dan bertransaksi dengan risiko investasi yang 
relatif (Dimitropoulos, 2009). Menurut Syafrudin (2004), investor merespon secara berbeda terhadap informasi laba akuntansi sesuai dengan kredibilitas atau kualitas informasi laba akuntansi tersebut. Adanya respon investor terhadap informasi laba, menunjukkan bahwa informasi laba itu memiliki kekuatan respon, dimana signifikan atau tidaknya kekuatan respon tersebut terhadap informasi laba dapat diukur menggunakan Earnings Response Coefficient (ERC).

ERC atau koefisien respon laba merupakan suatu efek dari setiap dolar unexpected earnings terhadap return saham, dan biasanya diukur dengan slope koefisien dalam regresi abnormal return saham dan unexpected earnings (Cho dan Jung, 1991 dalam Fariba, 2013). Definisi tersebut secara sederhana mengungkapkan bahwa koefisien respon laba merupakan besaran yang menunjukkan hubungan antara laba dan return saham. Besarnya koefisien slope dalam regresi yang menghubungkan laba sebagai variabel bebas dengan return saham sebagai variabel terikat menunjukkan koefisien respon laba.

Hasil penelitian empiris mengenai hubungan antara returns/earnings menunjukkan bahwa meskipun informasi laba digunakan oleh investor, tetapi kegunaan dari informasi laba tersebut bagi investor sangat terbatas (Lev, 1989 dalam Sayekti dan Wondabio, 2007). Informasi laba yang disajikan perusahaan melalui laporan keuangan, dianggap bias. Hal itu dikarenakan meskipun profit perusahaan dalam suatu periode mengalami peningkatan, belum dapat menjadi jaminan bahwa kinerja perusahaan memang benar-benar bagus. Adanya anggapan bahwa informasi laba yang disajikan adalah bias menyebabkan investor juga memerlukan sumber informasi lain yang dapat digunakan dalam pertimbangan sebelum melakukan investasi. Salah satu sumber informasi lain yang dapat digunakan sebagai pertimbangan bagi investor, khususnya bagi investor yang memiliki rencana untuk melakukan investasi dalam jangka panjang adalah informasi terkait aktivitas tanggung jawab sosial perusahaan (Corporate Social Responsibilty-CSR). 
Kondisi keuangan saja tidak cukup menjamin nilai perusahaan tumbuh secara berkelanjutan (sustainable), tetapi juga harus memperhatikan dimensi sosial dan ligkungan hidup (Untung, 2008). Apabila terjadi ketidakselarasan antara sistem nilai perusahaan dan sistem nilai masyarakat, maka perusahaan dapat kehilangan legitimasinya, yang selanjutnya akan mengancam kelangsungan hidup perusahaan (Lindblom, 1994 dalam Haniffa et al, 2005; Sayekti dan Wondabio, 2007). Pengungkapan CSR dalam laporan tahunan merupakan salah satu cara perusahaan untuk membangun, mempertahankan, dan melegitimasi kontribusi perusahaan dari sisi ekonomi dan politis (Guthrie dan Parker, 1990 dalam Sayekti dan Wondabio, 2007).

Saat ini, pemerintah juga telah menyadari pentingnya aktivitas CSR. Hal itu dibuktikan dari dikeluarkannya beberapa regulasi terkait CSR. Kewajiban mengenai pelaksanaan dan pengungkapan aktivitas CSR dinyatakan dalam Undang-Undang No. 40 Tahun 2007 tentang Perseroan Terbatas, pada Pasal 66 ayat (2) bagian c dan Pasal 74, serta dalam Peraturan Pemerintah No. 47 Tahun 2012 tentang Tanggung Jawab Sosial dan Lingkungan Perseroan Terbatas. Kedua pasal dalam Undang-Undang tersebut mengatur kewajiban perusahaan untuk melaporkan pelaksanaan tanggung jawab sosial dan lingkungan dalam laporan keuangan tahunan. Adanya UndangUndang yang mengatur mengenai kewajiban CSR, diharapkan perusahaan tidak lagi hanya terfokus pada kinerja keuangan saja, akan tetapi perlu memberikan penekanan pula terhadap kinerja sosial dan lingkungannya. Selain itu, dengan adanya UndangUndang dan Peraturan Pemerintah tersebut menyebabkan CSR tidak lagi dimaknai sebagai kegiatan perusahaan yang bersifat voluntary, melainkan mandatory.

Survei global yang dilakukan oleh The Economist Intelligence Unit menunjukkan bahwa $85 \%$ eksekutif senior dan investor dari berbagai organisasi menjadikan CSR sebagai pertimbangan utama dalam pengambilan keputusan (Warta Ekonomi, 2006 dalam Sayekti dan Wondabio, 2007). Survei tersebut membuktikan bahwa saat ini selain informasi yang tercakup dalam laba akuntansi, informasi CSR mulai dipertimbangkan pula dalam pengambilan keputusan. Adanya pengungkapan 
informasi CSR diharapkan dapat menjadi informasi tambahan kepada para investor selain informasi yang mereka dapatkan dari laba akuntansi.

Pengungkapan informasi CSR yang ikut menjadi pertimbangan investor sebelum melakukan investasi, menyebabkan respon investor terhadap informasi laba menjadi ikut terpengaruh. Hal itu dikarenakan investor tidak lagi hanya terfokus pada informasi laba untuk pengambilan keputusan investasinya. Sayekti dan Wondabio (2007) telah melakukan penelitian mengenai pengaruh pengungkapan Corporate Social Responsibility (CSR) terhadap Earnings Response Coefficient (ERC). Hasil dari penelitian tersebut menunjukkan CSR berpengaruh negatif terhadap ERC. Penelitian lain yang dilakukan oleh Daud dan Syarifuddin (2008) memiliki hasil temuan yang berbeda, yaitu CSR memiliki pengaruh positif dan siginifikan terhadap ERC. Penelitian yang terakhir dilakukan oleh Wulandari dan Wirajaya (2014) menemukan bahwa CSR tidak memiliki pengaruh yang signifikan terhadap ERC disebabkan oleh rendahnya keyakinan investor terhadap informasi CSR yang diungkapkan perusahaan, serta jumlah informasi CSR yang diungkapkan perusahaan relatif sedikit. Adanya ketidakkonsistenan hasil dari beberapa penelitian sebelumnya, mendorong peneliti untuk melakukan pengujian kembali terkait pengaruh pengungkapan CSR terhadap ERC pada dimensi waktu yang berbeda. Berdasarkan uraian yang telah dijelaskan, maka hipotesis yang diajukan adalah:

H1: Pengungkapan Corporate Social Responsibility (CSR) dalam laporan tahunan perusahaan memiliki pengaruh signifikan terhadap Earnings Response Coefficient (ERC).

\section{METODE PENELITIAN}

Variabel dependen dalam penelitian ini, yaitu CAR akan dihitung secara harian dalam periode 15 bulan mulai dari 1 Januari 2014 hingga 31 Maret 2015 dan periode 12 bulan, yaitu mulai dari 1 Januari 2014 hingga 31 Desember 2014 dan mulai 1 April 2014 hingga 31 Maret 2015. Penelitian menggunakan dua periode dikarenakan Collins et al (1989 dalam Lev, 1989; Sayekti dan Wondabio, 2007) 
dalam penelitian menemukan bahwa perhitungan return yang paling optimal adalah dalam jangka waktu 15 bulan, akan tetapi dalam penelitian tersebut tidak ada landasan teori yang kuat dan tidak disebutkan alasan mengapa jangka waktu 15 bulan adalah time interval yang paling optimal dalam perhitungan return. Penentuan window (time interval) untuk mengukur cumulative abnormal return (CAR) merupakan hal yang penting, karena apabila terlalu pendek, maka ukuran CAR tidak dapat menangkap reaksi pasar yang mungkin terjadi di luar window tersebut, misalnya karena reaksi investor yang lambat, serta sebaliknya jika time interval terlalu panjang, maka dapat memberikan pengukuran yang bias mengenai kontribusi informasi yang diungkapkan oleh perusahaan (Lev, 1989; Sayekti dan Wondabio, 2007). Perhitungan CAR merupakan akumulasi abnormal return untuk masingmasing perusahaan dalam periode 15 bulan dan 12 bulan. Rumus untuk perhitungan abnormal return adalah sebagai berikut :

$$
\begin{aligned}
& R_{i t}=\frac{\mathrm{P}_{i t}-\mathrm{P}_{i t-1}}{\mathrm{P}_{i t-1}} \\
& R_{m t}=\frac{\mathrm{IHSG}_{t}-\mathrm{IHSG}_{t-1}}{\mathrm{IHSG}_{t-1}} \\
& A R_{i t}=R_{i t}-R_{m t}
\end{aligned}
$$

Dimana :

$A R_{i t} \quad$ : Abnormal return untuk perusahaan i pada hari ke-t.

$R_{i t} \quad:$ Return harian perusahaan i pada hari ke-t.

$R_{m t} \quad$ : Return indeks pasar pada hari ke-t.

$\mathrm{P}_{i t} \quad$ : Harga saham perusahaan i pada waktu t.

$\mathrm{P}_{i t-1} \quad$ : Harga saham perusahaan i pada waktu t-1.

$\mathrm{IHSG}_{t}$ : Indeks Harga Saham Gabungan pada waktu t. 
$\mathrm{IHSG}_{t-1}$ : Indeks Harga Saham Gabungan pada waktu t-1.

Unexpected Earnings (UE) dan CSR disclosure index (CSRI) menjadi variabel independen dalam penelitian ini. Dengan menggunakan dasar asumsi random walk, variabel UE dihitung sebagai perubahan dari laba per lembar saham perusahaan tahun sekarang dikurangi dengan laba per lembar saham perusahaan tahun sebelumnya, dan diskalakan dengan harga per lembar saham pada akhir periode sebelumnya (Kothari dan Zimmerman, 1995). Berdasarkan penjelasan tersebut, maka variabel UE dalam penelitian ini dihitung dari laba per lembar saham perusahaan tahun 2014 dikurangi dikurangi dengan laba per lembar saham perusahaan tahun 2013, kemudian dibagi dengan harga per lembar saham pada 31 Desember 2013.

Pengukuran CSRI dalam penelitian ini mengacu pada pengelompokan informasi CSR ke dalam kategori lingkungan, energi, tenaga kerja, produk, keterlibatan masyarakat, dan umum (Sembiring, 2005). Total item CSR berkisar antara 63 sampai 78, tergantung dari jenis industri perusahaan (Sayekti dan Wondabio, 2007).

Perhitungan CSRI menggunakan pendekatan dikotomi yaitu setiap item CSR dalam instrumen penelitian diberi nilai 1 jika diungkapkan, dan nilai 0 jika tidak diungkapkan, yang kemudian skor dari setiap item tersebut dijumlahkan untuk memperoleh keseluruhan skor setiap perusahaan (Haniffa et al, 2005 dalam Sayekti dan Wondabio, 2007). Rumus perhitungan CSRI adalah sebagai berikut :

$$
\operatorname{CSRI}_{j}=\frac{\sum \mathrm{X}_{i j}}{\mathrm{n}_{j}}
$$

Dimana :

$\operatorname{CSRI}_{j}:$ : Corporate Social Responsibility Disclosure Index perusahaan j.

$\mathrm{n}_{j} \quad$ : jumlah item untuk perusahaan $\mathrm{j}, \mathrm{n}_{j} \leq 78$

$\mathrm{X}_{i j} \quad$ : dummy variabel: $1=$ jika item i diungkapkan; $0=$ jika item i tidak diungkapkan. 
Sehingga, skala $\operatorname{CSRI}_{j}$ adalah $0 \leq \operatorname{CSRI}_{j} \leq 1$

Untuk melihat pengaruh CSRI terhadap ERC, maka variabel UE dan variabel CSRI akan diinteraksikan dalam persamaan regresi dengan model interaksi.

Variabel kontrol dalam penelitian ini adalah BETA dan Price to Book Value (PBV). BETA merupakan proksi atas variabel risiko sistematik perusahaan sebagai variabel bebas yang merupakan salah satu faktor yang dapat mempengaruhi ERC. Pemegang saham (investor) akan memberi respon yang lebih besar kepada perusahaan dengan kemungkinan bertumbuh yang tinggi, sehingga growth opportunities yang diproksikan dengan PBV sebagai variabel bebas menjadi salah satu faktor yang juga dapat mempengaruhi ERC. BETA diprediksi berpengaruh negatif terhadap ERC, sedangkan PBV diprediksi akan berpengaruh positif terhadap ERC (Scott, 2015).

Penelitian ini menggunakan data sekunder berupa laporan tahunan perusahaan-perusahaan dalam periode 31 Desember 2014 yang terdaftar pada Bursa Efek Indonesia. Melalui laporan tahunan akan dapat diperoleh data mengenai pengungkapan aktivitas CSR yang dilakukan perusahaan pada periode tersebut. Untuk data harga saham yang digunakan dalam perhitungan return perusahaan dan return pasar diperoleh dari situs Yahoo Finance (www.finance.yahoo.com), data PBV diperoleh dari situs Bursa Efek Indonesia (www.idx.co.id), sedangkan untuk data BETA diperoleh dari situs Pefindo (www.pefindo.com). Selanjutnya, untuk data perusahaan seperti laba per lembar saham diperoleh dari laporan tahunan.

Objek yang digunakan dalam penelitian ini adalah perusahaan yang terdaftar dalam Bursa Efek Indonesia (BEI) periode 1 Januari 2013 hingga 31 Maret 2015. Perusahaan yang akan dipilih menjadi populasi harus memenuhi beberapa kriteria yang dibutuhkan dalam penelitian ini. Pertama, perusahaan tersebut mempublikasikan laporan tahunan untuk tahun 2014. Kedua, dalam laporan tahunan tersebut mengungkapkan aktivitas CSR yang telah dilakukan perusahaan yang bersangkutan, 
dimana untuk memastikan tersedianya pengungkapan CSR dapat dilihat melalui content daftar isi. Ketiga, perusahaan yang bersangkutan memiliki data stock price yang lengkap. Keempat, perusahaan memiliki data beta yang tersaji dalam PEFINDO. Kelima, perusahaan memiliki data performance profile, khususnya terkait informasi PBV yang tersedia lengkap dalam situs Indonesia Stock Exchange. Berdasarkan kriteria yang telah diuraikan, terpilih 285 perusahaan yang menjadi populasi dalam penelitian ini. Selanjutnya, sampel diambil dengan teknik purposive sampling, dimana melalui uji normalitas akan dieliminasi data perusahaan yang memiliki nilai outlier, sehingga sampel yang diambil sesuai dengan yang dibutuhkan dalam penelitian ini.

Data yang telah diperoleh akan diolah dan dianalisis lebih lanjut dengan menggunakan beberapa metode perhitungan statistika untuk mengetahui pengaruh pengungkapan CSR terhadap ERC. Pengolahan dan analisis data dilakukan dengan bantuan Microsoft Excel 2007 dan IBM SPSS Statistic 22. Pengujian asumsi klasik, yaitu uji normalitas, uji multikolinearitas, uji autokorelasi, dan uji heterokedastisitas juga dilakukan agar nilai parameter model penduga yang digunakan dinyatakan valid.

Pengujian hipotesis dilakukan menggunakan alat uji regresi berganda dengan dua model, yaitu:

- Model pertama yang meregresikan variabel CAR dengan variabel UE dan CSRI, serta interaksi keduanya, tanpa memasukkan variabel kontrol.

- Model kedua adalah model yang sudah memasukkan variabel kontrol, yaitu PBV beserta interaksinya dengan variabel UE.

Model I (tanpa variabel control)

$$
\mathrm{CAR}=\alpha_{0}+\alpha_{1} \mathrm{UE}+\alpha_{2} \mathrm{CSRI}+\alpha_{3} \mathrm{UE} * \mathrm{CSRI}+\varepsilon
$$

Model II (dengan variabel control)

$$
\begin{aligned}
\mathrm{CAR}= & \beta_{0}+\beta_{1} \mathrm{UE}+\beta_{2} \mathrm{CSRI}+\beta_{3} \mathrm{BETA}+\beta_{4} \mathrm{PBV}+ \\
& \beta_{5} \mathrm{UE} * \mathrm{CSRI}+\beta_{6} \mathrm{UE} * \mathrm{BETA}+\beta_{7} \mathrm{UE} * \mathrm{PBV}+\varepsilon
\end{aligned}
$$


Keterangan :

CAR : Cummulative Abnormal Return harian perusahaan selama periode 15 bulan ataupun 12 bulan, yaitu mulai 1 Januari 2014 hingga 31 Maret 2015, 1 Januari 2014 hingga 31

Desember 2014, dan 1 April 2014 hingga 31 Maret 2015.

UE : Unexpected Earnings perusahaan yang dihitung dengan menggunakan asumsi random walk, (laba per lembar saham tahun 2014 dikurangi dengan laba per lembar saham 2013), dan diskalakan dengan harga saham perusahaan pada akhir tahun 2013.

CSRI : Corporate Social Responsibility Disclosure Index (mengukur jenis dari CSR yang diungkapkan oleh perusahaan dalam laporan tahunannya).

BETA : beta koreksi yang merupakan proksi dari resiko.

PBV : rasio Price to Book Value yang merupakan proksi dari pertumbuhan perusahaan.

UE*CSRI : interaksi dari variabel UE dan CSRI

UE*BETA : interaksi dari variabel UE dan BETA

UE*PBV : interaksi dari variabel UE dan PBV

$\varepsilon$

: error term.

Apabila tingkat pengungkapan CSR mempengaruhi ERC maka diprediksi koefisien pada variabel UE*CSRI dari model I (tanpa variabel kontrol) akan signifikan. Sedangkan untuk melihat ada atau tidaknya pengaruh variabel kontrol BETA dan PBV terhadap ERC, maka dilihat signifikansi dari koefisien $\beta_{6}$ dan $\beta_{7}$ pada model II (dengan variabel kontrol). Untuk melihat signifikan atau tidak maka dilanjutkan uji t. Jika nilai t-hitung yaitu nilai Sig $<5 \%$, maka terdapat pengaruh yang signifikan. 


\section{HASIL DAN PEMBAHASAN}

\section{Hasil Statistik Deskriptif}

\section{CAR 1 Januari 2014-31 Maret 2015}

\section{Model I}

Tabel 1. Statistik Deskriptif

\begin{tabular}{|l|r|r|r|r|r|}
\hline & $\mathrm{N}$ & Minimum & Maximum & \multicolumn{1}{c|}{ Mean } & Std. Deviation \\
\hline CAR & 270 & -.991 & .861 & -.06525 & .374435 \\
UE & 270 & -.521 & 477.160 & 1.85588 & 29.051055 \\
CSRI & 270 & .013 & .551 & .18472 & .124630 \\
UE*CSRI & 270 & -.136 & 103.996 & .39339 & 6.329382 \\
Valid N (listwise) & 270 & & & & \\
\hline
\end{tabular}

Sumber: hasil olahan SPSS

\section{Model II}

Tabel 2. Statistik Deskriptif

\begin{tabular}{|l|r|r|r|r|r|}
\hline & $\mathrm{N}$ & Minimum & Maximum & \multicolumn{1}{c|}{ Mean } & Std. Deviation \\
\hline CAR & 270 & -.991 & .978 & -.06465 & .376004 \\
UE & 270 & -.521 & 477.160 & 1.85603 & 29.051045 \\
CSRI & 270 & .013 & .551 & .18637 & .124741 \\
BETA & 270 & .003 & 2.686 & .87873 & .579794 \\
PBV & 270 & -241.68 & 45.03 & 1.3229 & 15.38583 \\
UE*CSRI & 270 & -.136 & 103.996 & .39344 & 6.329379 \\
UE*BETA & 270 & -1.004 & 647.506 & 2.43710 & 39.405570 \\
UE*PBV & 270 & -2.025 & 682.339 & 2.59441 & 41.531828 \\
Valid N (listwise) & 270 & & & & \\
\hline
\end{tabular}

Sumber: hasil olahan SPSS

\section{CAR 1 Januari 2014-31 Desember 2014}

\section{Model I}

Tabel 3. Statistik Deskriptif

\begin{tabular}{|l|r|r|r|r|r|}
\hline & \multicolumn{1}{|c|}{ N } & Minimum & Maximum & \multicolumn{1}{l|}{ Mean } & \multicolumn{1}{c|}{ Std. Deviation } \\
\hline CAR 1 Jan 2014-31 Des 2014 & 267 & -.734 & .751 & -.01489 & .325782 \\
UE & 267 & -.521 & 477.160 & 1.87408 & 29.213886 \\
CSRI & 267 & .013 & .551 & .18546 & .124959 \\
UE*CSRI & 267 & -.136 & 103.996 & .39771 & 6.364842 \\
Valid N (listwise) & 267 & & & & \\
\hline
\end{tabular}

Sumber: hasil olahan SPSS 


\section{Model II}

Tabel 4. Statistik Deskriptif

\begin{tabular}{|l|r|r|r|r|r|}
\hline & N & Minimum & Maximum & \multicolumn{1}{c|}{ Mean } & Std. Deviation \\
\hline CAR 1 Jan 2014-31 Des 2014 & 265 & -.734 & .751 & -.01959 & .322395 \\
UE & 265 & -.521 & 477.160 & 1.88030 & 29.324101 \\
CSRI & 265 & .013 & .551 & .18526 & .125375 \\
BETA & 265 & .003 & 2.686 & .88164 & .574445 \\
PBV & 265 & -241.68 & 45.03 & 1.3673 & 15.61243 \\
UE*CSRI & 265 & -.136 & 103.996 & .39930 & 6.388858 \\
UE*BETA & 265 & -1.004 & 647.506 & 2.47751 & 39.775831 \\
UE*PBV & 265 & -2.025 & 682.339 & 2.64367 & 41.921691 \\
Valid N (listwise) & 265 & & & & \\
\hline
\end{tabular}

Sumber: hasil olahan SPSS

\section{CAR 1 April 2014-31 Maret 2015}

\section{Model I}

Tabel 5. Statistik Deskriptif

\begin{tabular}{|l|r|r|r|r|r|}
\hline & N & Minimum & Maximum & \multicolumn{1}{c|}{ Mean } & Std. Deviation \\
\hline CAR 1 Apr 2014-31 Mar 2015 & 266 & -.797 & .766 & -.06736 & .311269 \\
UE & 266 & -.521 & 477.160 & 1.88365 & 29.268593 \\
CSRI & 266 & .013 & .551 & .18637 & .125489 \\
UE*CSRI & 266 & -.136 & 103.996 & .39925 & 6.376790 \\
Valid N (listwise) & 266 & & & & \\
\hline
\end{tabular}

Sumber: hasil olahan SPSS

\section{Model II}

Tabel 6. Statistik Deskriptif

\begin{tabular}{|l|r|r|r|r|r|}
\hline & N & Minimum & Maximum & \multicolumn{1}{c|}{ Mean } & Std. Deviation \\
\hline CAR 1 Apr 2014-31 Mar 2015 & 265 & -.797 & .777 & -.06457 & .310118 \\
UE & 265 & -.521 & 477.160 & 1.89046 & 29.323763 \\
CSRI & 265 & .013 & .551 & .18631 & .125511 \\
BETA & 265 & .003 & 2.686 & .87979 & .577898 \\
PBV & 265 & -241.68 & 45.03 & 1.2523 & 15.49300 \\
UE*CSRI & 265 & -.136 & 103.996 & .40073 & 6.388810 \\
UE*BETA & 265 & -1.004 & 647.506 & 2.48284 & 39.775553 \\
UE*PBV & 265 & -2.025 & 682.339 & 2.64348 & 41.921717 \\
Valid N (listwise) & 265 & & & & \\
\hline
\end{tabular}

Sumber: hasil olahan SPSS 
Berdasarkan hasil uji statistik deskriptif pada model I dan model II dalam dua periode, menunjukkan bahwa rata-rata pengungkapan informasi CSR yang dilakukan perusahaan masih sangat minim, yaitu kurang dari 50 persen. Rata-rata CSRI sebesar 0,186, memperlihatkan adanya penurunan jika dibandingkan dengan penelitian sebelumnya pada tahun 2005 yang dilakukan oleh Sayekti, yaitu sebesar 0,202. Semakin rendahnya rata-rata dari CSRI, menunjukkan bahwa saat ini perusahaan semakin kurang menaruh perhatian terhadap pengungkapan aktivitas CSR dalam laporan tahunan.

Pengujian asumsi klasik, yaitu pada hasil uji multikolinearitas, diketahui terjadi gejala mutikolinearitas yang tinggi pada variabel UE, UE* CSRI, UE*BETA, dan UE*PBV. Gejala multikolinearitas yang tinggi disebabkan karena adanya efek kombinasi dua variabel independen. Semua variabel dengan nilai VIF tertinggi saling berhubungan dengan variabel UE, sehingga dapat disimpulkan bahwa variabel independen yang memiliki kolinearitas tertinggi adalah variabel UE. Akan tetapi, variabel UE tidak dapat dikeluarkan dari model. Hal tersebut dikarenakan variabel UE merupakan variabel utama yang akan dilakukan pengujian.

\section{Analisis Regresi Linier Berganda}

\section{Model I}

Tabel 7. Analisis Regresi Linier Berganda

\begin{tabular}{|c|c|c|c|c|c|c|c|c|c|c|c|}
\hline \multirow{2}{*}{ Variabel } & \multicolumn{3}{|c|}{$\begin{array}{l}\text { CAR 1 Januari 2014-31 Maret } \\
2015 \\
\end{array}$} & \multicolumn{3}{|c|}{$\begin{array}{c}\text { CAR } 1 \text { Januari 2014-31 } \\
\text { Desember 2014 } \\
\end{array}$} & \multicolumn{3}{|c|}{ CAR 1 April 2014-31 Maret 2015} & \multirow{2}{*}{ Hasil } & \multirow[b]{2}{*}{ Keterangan } \\
\hline & B & $\mathbf{t}$ & $\begin{array}{c}\text { Tingkat } \\
\text { Signifikansi }\end{array}$ & B & $\mathbf{t}$ & $\begin{array}{c}\text { Tingkat } \\
\text { Signifikansi } \\
\end{array}$ & B & $\mathbf{t}$ & $\begin{array}{c}\text { Tingkat } \\
\text { Signifikansi }\end{array}$ & & \\
\hline UE & $-0,031$ & $-0,747$ & 0,456 & $-0,022$ & $-0,603$ & 0,547 & 0,005 & 0,152 & 0,879 & & $\begin{array}{c}\text { tidak } \\
\text { signifikan }\end{array}$ \\
\hline CSRI & $-0,271$ & $-1,477$ & 0,141 & $-0,21$ & $-0,135$ & 0,893 & $-0,190$ & $-1,249$ & 0,213 & & $\begin{array}{c}\text { tidak } \\
\text { signifikan }\end{array}$ \\
\hline UE*CSRI & 0,146 & 0,767 & 0,444 & 0,107 & 0,646 & 0,519 & $-0,020$ & $-0,126$ & 0,900 & $\begin{array}{c}\text { H0 } \\
\text { diterima, } \\
\text { H1 } \\
\text { ditolak } \\
\end{array}$ & $\begin{array}{l}\text { tidak } \\
\text { signifikan }\end{array}$ \\
\hline
\end{tabular}

Sumber: hasil olahan SPSS 


\section{Model II}

Tabel 8. Analisis Regresi Linier Berganda

\begin{tabular}{|c|c|c|c|c|c|c|c|c|c|c|c|}
\hline \multirow[b]{2}{*}{ Variabel } & \multicolumn{3}{|c|}{ CAR 1 Januari 2014-31 Maret 2015} & \multicolumn{3}{|c|}{ CAR 1 Januari 2014-31 Desember 2014} & \multicolumn{3}{|c|}{ CAR 1 April 2014-31 Maret 2015} & \multirow[b]{2}{*}{ Hasil } & \multirow[b]{2}{*}{ Keterangan } \\
\hline & B & $\mathbf{t}$ & $\begin{array}{c}\text { Tingkat } \\
\text { Signifikansi }\end{array}$ & B & $\mathbf{t}$ & $\begin{array}{c}\text { Tingkat } \\
\text { Signifikansi }\end{array}$ & B & $\mathbf{t}$ & $\begin{array}{c}\text { Tingkat } \\
\text { Signifikansi }\end{array}$ & & \\
\hline UE & 0,009 & 0,212 & 0,832 & 0,000 & $-0,011$ & 0,991 & 0,024 & 0,658 & 0,511 & & $\begin{array}{c}\text { tidak } \\
\text { signifikan }\end{array}$ \\
\hline CSRI & $-0,130$ & $-0,729$ & 0,466 & 0,004 & 0,026 & 0,980 & $-0,241$ & $-1,584$ & 0,114 & & $\begin{array}{c}\text { tidak } \\
\text { signifikan }\end{array}$ \\
\hline BETA & 0,177 & 4,563 & 0,000 & 0,154 & 4,577 & 0,000 & 0,042 & 1,262 & 0,208 & & signifikan \\
\hline PBV & 0,000 & 0,128 & 0,898 & 0,001 & 0,865 & 0,388 & 0,000 & $-0,298$ & 0,766 & & $\begin{array}{c}\text { tidak } \\
\text { signifikan }\end{array}$ \\
\hline $\mathrm{UE}^{*} \mathrm{CSRI}$ & $-2,379$ & $-0,176$ & 0,861 & $-22,678$ & $-1,477$ & 0,141 & $-11,145$ & $-0,792$ & 0,429 & $\begin{array}{c}\text { H0 } \\
\text { diterima, } \\
\text { H1 } \\
\text { ditolak }\end{array}$ & $\begin{array}{c}\text { tidak } \\
\text { signifikan }\end{array}$ \\
\hline UE*BETA & 0,026 & 0,894 & 0,372 & 0,023 & 0,907 & 0,365 & 0,018 & 0,705 & 0,481 & & $\begin{array}{c}\text { tidak } \\
\text { signifikan }\end{array}$ \\
\hline UE*PBV & $-0,031$ & $-0,695$ & 0,488 & $-0,020$ & $-0,520$ & 0,604 & $-0,033$ & $-0,869$ & 0,386 & & $\begin{array}{c}\text { tidak } \\
\text { signifikan }\end{array}$ \\
\hline
\end{tabular}

Sumber: hasil olahan SPSS

Hasil pengujian pada model I menunjukkan bahwa tingkat pengungkapan CSR dalam laporan tahunan memiliki korelasi positif dengan ERC. Sedangkan pada pengujian model II menunjukkan adanya korelasi negatif antara pengungkapan CSR terhadap ERC. Adanya korelasi negatif tersebut kemungkinan disebabkan karena investor mempertimbangkan bahwa ketika perusahaan semakin banyak dalam melakukan pengungkapan informasi (peningkatan informativeness of earnings), menunjukkan terdapat ketidakpastian prospek perusahaan tersebut di masa depan, sehingga menurunkan nilai dari ERC, begitu pula sebaliknya.

Hasil pengujian pada model II sejalan dengan hasil penelitian yang dilakukan oleh Sayekti (2007). Akan tetapi, hasil tersebut bertolak belakang dengan hasil penelitian yang dilakukan oleh Lang dan Lundholm (1996) dan Holbrook (2013). Penelitian Lang dan Lundholm (1996) menyatakan bahwa ketika perusahaan semakin tinggi melakukan pengungkapan informasi, maka akan meningkatkan jumlah investor 
following karena mereka dapat melakukan prediksi secara lebih akurat. Penelitian Holbrook (2013) menyatakan bahwa terdapat korelasi positif antara CSR dan ERC.

Terlepas dari korelasi antara tingkat pengungkapan CSR dalam laporan tahunan terhadap ERC, pengujian kedua model dengan menggunakan CAR periode 15 bulan maupun 12 bulan tersebut menunjukkan tidak adanya pengaruh yang signifikan antara tingkat pengungkapan CSR dalam laporan tahunan terhadap ERC. Hasil penelitian ini mengindikasikan bahwa luas pengungkapan CSR tidak mampu membantu investor untuk menilai persistensi laba perusahaan di masa depan. Hal itu dapat disebabkan karena investor tidak sepenuhnya percaya terhadap informasi CSR yang diungkapkan perusahaan dalam laporan tahunannya. Rata-rata pengungkapan informasi CSR perusahaan yang sangat minim, yaitu kurang dari 50 persen menyebabkan bagi para investor yang ingin melakukan investasi jangka dengan mempertimbangkan informasi CSR tidak akan mendapat informasi yang cukup, sehingga hal itu menyebabkan luas pengungkapan CSR tidak memiliki pengaruh yang signifikan tehadap ERC.

Hasil penelitian ini sejalan dengan hasil penelitian yang dilakukan oleh Alexander dan Buchholz (1978) serta Wulandari dan Wirajaya (2014). Penelitian yang dilakukan oleh Alexander dan Buchholz (1978) menyatakan bahwa CSR tidak memiliki pengaruh terhadap kinerja stock market, atau adanya pengaruh tersebut hanya terjadi sebelum tahun 1970 dan hal ini sejalan dengan teori pasar efisien Fama (1970). Penelitian Wulandari dan Wirajaya (2014) menyatakan pengungkapan CSR tidak berpengaruh terhadap ERC karena investor lebih berorientasi pada kinerja jangka pendek dan informasi CSR yang diungkapkan perusahaan masih relatif sedikit.

Melalui penelitian ini, diketahui bahwa pengungkapan informasi CSR belum dapat digunakan oleh investor sebagai bahan pertimbangan untuk melakukan investasi. Selain itu, melalui penelitian ini juga diketahui bahwa perhatian perusahaan terhadap pengungkapan aktivitas CSR dalam laporan tahunan masih rendah, serta 
masih terdapat perusahaan yang tidak melakukan pengungkapan aktivitas CSR. Padahal seperti yang telah diketahui bahwa pemerintah telah mengeluarkan peraturan mengenai kewajiban bagi Perseroan Terbatas untuk melaksanakan CSR serta mengungkapkan aktivitas tersebut dalam laporan tahunan. Peraturan itu tercantum dalam UU No. 40 Tahun 2007 tentang Perseroan Terbatas pada Pasal 66 ayat (2) bagian c dan Pasal 74, serta dalam Peraturan Pemerintah No. 47 Tahun 2012 tentang Tanggung Jawab Sosial dan Lingkungan Perseroan Terbatas. Adanya peraturanperaturan tersebut menyebabkan pelaksanaan maupun pengungkapan aktivitas CSR dalam laporan tahunan perusahaan menjadi kegiatan perusahaan yang bersifat mandatory, tidak lagi voluntary.

Tidak adanya pengawasan yang ketat oleh pemerintah terhadap aktivitas pengungkapan CSR menyebabkan perusahaan mengesampingkan hal itu. Selain itu, tidak adanya aturan yang jelas dari pemerintah dan badan pembuat standar akuntansi terkait detail pengungkapan aktivitas CSR, seperti item-item apa saja yang harus diungkapkan, membuat pengungkapan CSR dalam laporan tahunan menjadi minim. Hal-hal tersebut yang kemudian menyebabkan informasi CSR dalam laporan tahunan menjadi tidak dapat digunakan investor untuk menjadi bahan pertimbangan dalam pengambilan keputusan investasi. Oleh karena itu, pemerintah dan badan pembuat standar akuntansi seharusnya mulai membuat peraturan yang lebih detail atau spesifik, serta memperketat pengawasan terhadap aturan yang telah ditetapkan terhadap pelaksanaan dan pengungkapan aktivitas CSR dalam laporan tahunan. Apabila hal itu tidak dilakukan, maka percuma saja telah ditetapkan peraturan terkait pelaksanaan dan pengungkapan aktivitas CSR dalam laporan tahunan, karena hal itu tidak akan memiliki dampak apapun, khususnya bagi investor.

\section{KESIMPULAN DAN SARAN}

Hasil penelitian ini menunjukkan bahwa pengungkapan CSR dalam laporan keuangan tahunan perusahaan tidak memiliki pengaruh yang signifikan terhadap respon investor atas informasi laba yang diukur dengan ERC. Hal ini menunjukkan 
bahwa investor tidak menggunakan informasi CSR perusahaan sebagai pertimbangan dalam pengambilan keputusan investasi.

Penelitian selanjutnya dapat menggunakan periode yang lebih panjang, sehingga hasil yang diperoleh semakin akurat. Selain itu, penelitian selanjutnya diharapkan dapat menggunakan variabel-variabel kontrol lain yang berpengaruh terhadap ERC, seperti leverage, persistensi, dan kualitas laba, serta menganalisis pengungkapan CSR dengan memerhatikan kesinambungan dari aktivitas CSR yang dilakukan perusahaan atau dengan kata lain analisis dilakukan berdasarkan pengungkapan program CSR yang dijalankan perusahaan, serta mencari metode perhitungan untuk pengukuran tingkat pengungkapan program CSR tersebut. 


\section{DAFTAR PUSTAKA}

Alexander, Gordon J. dan Rogene A. Buchholz. 1978. Corporate Social Responsibility and Stock Market Performance. The Academy of management Journal, Vol. 21, Issue 3, 479-486

Daud, R. M., dan N. A. Syarifuddin. 2008. Pengaruh Corporate Social Responsibility Disclosure, Timelineness, dan Debt to Equity Ratio terhadap Earnings Response Coefficient. Jurnal Telaah dan Riset Akuntansi. Vol. 1 (1): h. 82101

Dimitropoulos, P.E., and D. Asteriou. 2009. The relationship between Earnings and Stock Return: Empirical Evidence from The Greek Capital Market. International Journal of Economics and Finance. Vol, 1 (1)

Fariba, Kazemzadeh. 2013. Effect of The Social Accountability on Incoming and Earnings Response Constant. Progress in Management Sciences Journal. Vol, $1(1):$ p. $8-14$

Holbrook, Mary Beth. 2013. Corporate Social Responsibility and Earnings Response Coefficients. Journal of Finance and Accountancy

Kothari dan J.L. Zimmerman. 1995. Price and Return Models. Journals of Accounting and Economics. Vol. 20, p.155-192

Lang, Mark H. dan Russell J. Lundholm. 1996. Corporate Disclosure Policy and Analyst Behavior. The Accounting Review. Vol. 71, No. 4, p.467-492

Peraturan Pemerintah No.47 Tahun 2012 tentang Tanggung Jawab Sosial dan Lingkungan Perseroan Terbatas

Sayekti, Y., dan L. S. Wondabio. 2007. Pengaruh CSR Disclosure terhadap Earnings Response Coefficient: Suatu Studi Empiris pada Perusahaan yang Terdaftar di Bursa Efek Jakarta). Simposium Nasional Akuntansi $X$

Scott, William R. 2015. Financial Accounting Theory, $7^{\text {th }}$ ed. Toronto: Pearson Education Canada

Sembiring, Eddy Rismanda. 2005. Karakteristik Perusahaan dan Pengungkapan Tanggung jawab Sosial: Study Empiris pada Perusahaan yang Tercatat di Bursa Efek Jakarta. Simposium Nasional Akuntansi VIII 
Syafrudin, M. 2004. Pengaruh Ketidaktepatwaktuan Penyampaian Laporan Keuangan pada Earnings Response Coefficient. Simposium Nasional Akuntansi VII

Undang- Undang No. 40 Tahun 2007 tentang Perseroan Terbatas Pasal 66 Ayat 2(c)

Undang- Undang No. 40 Tahun 2007 tentang Perseroan Terbatas Pasal 74

Untung, H.B. 2008. Corporate Social Responsibility. Jakarta: Sinar Grafika

Wulandari, K.T., dan G. A. Wirajaya. 2014. Pengaruh Pengungkapan Corporate Social Responsibility terhadap Earnings Response Coefficient. E-Jurnal Akuntansi Universitas Udayana 6.3. Vol. 6, No.3. http://ojs.unud.ac.id/index.php/Akuntansi/article/view/8330/0. (diunduh tanggal 11 April 2015) 